ISSN 1392-3196 / e-ISSN 2335-8947

Zemdirbyste-Agriculture, vol. 102, No. 3 (2015), p. 251-256

DOI $10.13080 / \mathrm{z}-\mathrm{a} .2015 .102 .032$

\title{
The distribution of phosphorus forms and fractions in Retisol under different soil liming management
}

\author{
Ieva JOKUBAUSKAITE $\dot{E}^{1}$, Danute KARČAUSKIENE $\dot{E}^{1}$, Šarūnas ANTANAITIS ${ }^{2}$, \\ Jonas MAŽVILA ${ }^{2}$, Alvyra ŠLEPETIENË ${ }^{3}$, Donatas KONČIUS ${ }^{1}$, \\ Loreta PIAULOKAITÉ-MOTUZIENE் ${ }^{1}$ \\ ${ }^{1}$ Vèžaičiai Branch, Lithuanian Research Centre for Agriculture and Forestry \\ Gargždų 29, Vèžaičiai, Klaipėda distr., Lithuania \\ E-mail: jokubauskaite.ieva@gmail.com \\ ${ }^{2}$ Agrochemical Research Laboratory, Research Centre for Agriculture and Forestry \\ Savanorių 287, Kaunas, Lithuania \\ ${ }^{3}$ Institute of Agriculture, Lithuanian Research Centre for Agriculture and Forestry \\ Instituto 1, Akademija, Kėdainiai distr., Lithuania
}

\begin{abstract}
Investigations on phosphorus (P) distribution in a naturally acid and limed moraine loam, Bathypogleyic Dystric Glossic Retisol were conducted in a site of a long-term experiment at the Véžaičiai Branch of Lithuanian Research Centre for Agriculture and Forestry in 2008 and 2011. The aim of the present study was to determine the distribution of different phosphorus forms and fractions in naturally acid soil limed for a long time (62 years). During this study different amounts (18.4 and $\left.104.9 \mathrm{t} \mathrm{ha}^{-1}\right)$ of lime materials were incorporated into the soil and affected the formation of two soil $\mathrm{pH}_{\mathrm{KCl}}$ levels - acidic (5.6) and near to neutral (6.7). Seven different organic and mineral phosphate fractions and plant-available phosphorus were determined in the soil.

The long-term soil liming was found to have no significant effect on the total P content and its distribution, but caused the changes in the proportions between the different phosphorus forms. Major part of mineral (74.02$83.68 \%$ ) and organic (88.9-93.8\%) $\mathrm{P}$ was composed of $\mathrm{Al}$ and Fe phosphates. Soil liming using $\times 2.0$ liming rates every 3-4 years influenced a significant increase of the phosphates $\left(\mathrm{AlPO}_{4}\right.$ and $\left.\mathrm{Al}(\mathrm{Fe}) \mathrm{PO}_{4}\right)$ little-available to plants obtained by the second cycle of extraction. It was determined that when soil $\mathrm{pH}$ becomes near to neutral, water soluble and plant-available $\mathrm{P}$ increases compared to its value measured at native $\mathrm{pH}$. Increase of soil $\mathrm{pH}_{\mathrm{KCl}}$ till 6.7 had a significant effect on the amount of little plant-available $\mathrm{Ca}$ phosphates and less soluble organic phosphorus fraction amount in soil. The relatively optimal amounts of phosphorus fractions available for plants were determined in the soil with a $\mathrm{pH}_{\mathrm{KCl}}$ of 5.6, achieved by liming with a 0.5 rate every 7 years.
\end{abstract}

Key words: acid soil, liming, organic and mineral phosphorus, phosphorus fractions.

\section{Introduction}

Phosphorus $(\mathrm{P})$ is a crucial element for the growth of plants and other living organisms such as microbes as it has a predominant role in cellular metabolism as adenosine triphosphate (ATP) and as an important part of many structural and biochemically functional components, but when present in excess it can lead to environmental problems such as eutrophication of aquatic ecosystems (Devau et al., 2011). With increasing demand for agricultural production, phosphorus is receiving more attention as a non-renewable resource. One unique characteristic of phosphorus is its low availability due to slow diffusion and high fixation in the soil. All of this means that phosphorus can be a major limiting factor for plant growth. Effective soil P management from both environmental and agronomic point of view requires the knowledge of phosphorus forms that determines its availability (Cordell et al., 2009).

As a major indicator of soil fertility and quality, soil total $\mathrm{P}$ is generally used to represent the phosphorus level in soil (Liu et al., 2013). Phosphorus occurs in soil in a wide range of organic and inorganic compounds. These phosphorus forms differ in their behaviour (different bonding strengths, stabilities, and degrees of biological availability) in soils (Moazed et al., 2010). Inorganic phosphorus usually accounts for $35 \%$ to $70 \%$ of the total $\mathrm{P}$ in soils. Inorganic phosphorus in the form of orthophosphate is a primary constituent of most P fertilisers. When added to soil, orthophosphate is either sequestered into forms that are not immediately available to plants (McLaughlin et al., 2011). Other forms of inorganic phosphorus commonly found in soil include pyrophosphate and polyphosphate which could be associated with high levels of microorganisms' activity (Makarov et al., 2005; Bünemann et al., 2008). Organic phosphorus generally accounts for $30 \%$ to $65 \%$ of the total P in soils. Soil organic phosphorus mainly exists in stabilized forms such as inositol phosphates and phosphonates, and active forms such as orthophosphate diesters and organic polyphosphates (Condron et al., 2005; Nash et al., 2014). The organic phosphorus can be released through mineralization processes mediated by soil organisms and plant roots in association with phosphatase secretion. These processes are highly influenced by soil moisture, temperature, surface physico-chemical properties and soil pH (Liu et al., 2013). Mobility of phosphorus is strongly affected by its reactions with soil constituents. All 
forms of organic phosphorus are significantly positively correlated with the organic matter content but negatively correlated with the $\mathrm{Al}$ and $\mathrm{Fe}$ contents. Organic phosphorus becomes available to plants only when the organic matter is decomposed (Wang et al., 2012). During the decomposition of organic phosphorus compounds, the amount of inorganic phosphorus increases in the soil which could be taken up by plants and thus returned into the soil P cycle (Noack et al., 2012). The larger part of total $P$ is converted into the less-soluble phosphorus forms and fractions and becomes unavailable or little-available to plants. The availability of soil $\mathrm{P}$ is extremely complex and needs to be systemically evaluated because it is highly associated with phosphorus dynamics and transformation among various phosphorus pools (Murphy, Sims, 2012). Many attempts have been made to describe the sequence of reactions that lead to phosphorus retention in acid soils. In acid soils, $\mathrm{P}$ is fixed into slightly soluble forms by precipitation and sorption reactions with $\mathrm{Fe}$ and $\mathrm{Al}$ compounds as well as crystalline and amorphous colloids. Phosphorus sorption is highly correlated with the clay content and with amorphous $\mathrm{Fe}$ and Al oxides content (Tripolskaja, 2003; Pizzeghello et al., 2011). Nevertheless, there is limited information on the behaviour and availability of phosphorus in acid soils.

Liming is the most efficient way to increase the plant-availability of soil $\mathrm{P}$, because it allows controlling the soil acidity and achieving the soil $\mathrm{pH}$. As has been described in the works conducted by other investigators (Murphy, Stevens, 2010; Murphy, Sims, 2012), there is evidence to suggest that liming could be used as a potential measure for the increasing the plant-availability of soil P. The primary goal of liming is to increase soil $\mathrm{pH}$, to decrease $\mathrm{Al}$ toxicity and other problems associated with acidic conditions. Another primary reason commonly advocated for liming acid soils is to improve phosphorus availability. The increase of soil available $\mathrm{P}$ in acid soils is associated with the reduction of $\mathrm{Fe}^{3+}$ and $\mathrm{Al}^{3+}$ ions in the soil solution. With increasing soil $\mathrm{pH}$, solubility of $\mathrm{Fe}$ and $\mathrm{Al}$ phosphates decreases (Devau et al., 2011). The $\mathrm{P}$ adsorbed on various clays and $\mathrm{Al} / \mathrm{Fe}$ oxides can be released by desorption reactions. However, liming has been reported to increase, decrease, or not affect the phosphorus that can be extracted from soil (Elser, Bennett, 2011; Murphy, Sims, 2012; Crews, Brookes, 2014). Crews and Brookes (2014) reported that small additions of lime to acid soil greatly increased the uptake of phosphorus, but liming to $\mathrm{pH} 7$ reduced $\mathrm{P}$ uptake. Researchers showed that phosphorus is most readily available between pH 6 and 7. Availability is governed by solubility and how readily phosphorus becomes fixed in soils. Fixation onto colloidal iron surfaces at very low pH levels, usually below 4, is seldom the dominant phosphorus fixation process in most soils. Phosphorus fixation with aluminium is more commonly seen from $\mathrm{pH} 4.5$ to 6 and results in substantial lock-up of $\mathrm{P}$, while in less acid to neutral $\mathrm{pH}$ soils $\mathrm{Ca}$ phosphate is the more commonly encountered inorganic form of P. Lime application rates should be targeted to achieve $\mathrm{pH}$ levels of between 5.2 and 5.5. Liming above this $\mathrm{pH}$ increased $\mathrm{P}$ uptake, probably due to improved root growth, although increased mineralisation and subsequent supply of $\mathrm{P}$ from organic matter (Sarker et al., 2014). Therefore, studies are needed to understand the interaction of lime and phosphorus on the availability of $P$.

The aim of our study was to determine the distribution of different phosphorus forms and fractions in naturally acid soil limed for a long time (62 years).

\section{Materials and methods}

Study site description. The research was carried out in 2008 and 2011 at a site of a long-term experiment, conducted at Véžaičiai Branch of Lithuanian Research Centre for Agriculture and Forestry. This long-term (1949-2011) field experiment was started in 1949 on a Bathypogleyic Dystric Glossic Retisol (RT-gs.dy.gld) (World reference base..., 2014) with a texture of sandy moraine loam. Before the start of the experiment the arable soil layer thickness was $20 \mathrm{~cm}$, soil carbonates were found deeper than 2 meters below the surface. Arable soil layer was very acid $\left(\mathrm{pH}_{\mathrm{KCl}} 4.2\right)$, high levels of aluminium (plant-available $\mathrm{Al} 60 \mathrm{mg} \mathrm{kg}^{-1}$ ), low levels of phosphorus (plant-available $\mathrm{P}_{2} \mathrm{O}_{5} 50 \mathrm{mg} \mathrm{kg}^{-1}$ ) and potassium (plantavailable $\mathrm{K}_{\mathrm{O}} \mathrm{O} 130 \mathrm{mg} \mathrm{kg}^{-1}$ ) were established in the arable soil layer. Application of the long-term liming system primary (1949), repeated (1965) and periodical liming (1985-2005) - during the period of 1949-2005, affected the formation of various soil $\mathrm{pH}$ levels (Table 1). It was the background for the estimation of the distribution of phosphorus $(\mathrm{P})$ forms and fractions.

Table 1. Experimental design of long-term periodical liming (liming rate calculated based on the soil hydrolytic acidity)

\begin{tabular}{|c|c|c|c|c|}
\hline \multirow[b]{2}{*}{ Treatment } & \multicolumn{3}{|c|}{ Amount of $\mathrm{CaCO}_{3}$ applied $\mathrm{t} \mathrm{ha}^{-1}$} & \multirow{2}{*}{$\begin{array}{l}\text { Total amount } \\
\text { of CaCO } \\
\text { applied } \\
\text { tha-1 } \\
(1949-2005)\end{array}$} \\
\hline & $\begin{array}{c}\text { primary } \\
\text { liming } \\
(1949)\end{array}$ & $\begin{array}{c}\text { repeated } \\
\text { liming } \\
(1965)\end{array}$ & $\begin{array}{l}\text { periodical } \\
\text { liming } \\
(1985-2005)\end{array}$ & \\
\hline Unlimed, $\mathrm{pH}_{\mathrm{KCl}} 4.2 \pm 0.01$ & 0 & 0 & 0 & - \\
\hline Limed at 0.5 rate every 7 years $\left(3.3 \mathrm{tha}^{-1} \mathrm{CaCO}_{3}\right), \mathrm{pH}_{\mathrm{KCl}} 5.6 \pm 0.05$ & 3.3 & 3.4 & 11.4 & 18.1 \\
\hline Limed at 2.0 rates every $3-4$ years $\left(15.0 \mathrm{t} \mathrm{ha}^{-1} \mathrm{CaCO}_{3}\right), \mathrm{pH}_{\mathrm{KCl}} 6.7 \pm 0.06$ & 13.2 & 1.7 & 90.0 & 104.9 \\
\hline
\end{tabular}

Crop rotation pattern in 1949-2005: 1) fodder beet, treated with $40 \mathrm{t} \mathrm{ha}^{-1}$ of farmyard manure and $\mathrm{N}_{68} \mathrm{P}_{80} \mathrm{~K}_{120}$, 2) barley undersown with perennial grasses $\left.-\mathrm{N}_{60}{ }_{60} \mathrm{P}_{60} \mathrm{~K}_{60}, 3\right)$ perennial grasses $\left.-\mathrm{P}_{60} \mathrm{~K}_{60}, 4\right)$ perennial grasses $\left.-\stackrel{\mathrm{P}}{60}_{60} \mathrm{~K}_{60}, 5\right)$ winter wheat $\left.-\stackrel{60}{\mathrm{~N}}_{60} \mathrm{P}_{60} \mathrm{~K}_{60}, 6\right)$ peabarley mixture for grain $-\mathrm{P}_{60} \mathrm{~K}_{60}$, 7) vetch-oat mixture for forage $-\mathrm{P}_{60} \mathrm{~K}_{60}$. In 2008, the long-term experiment was restructured - the crop rotation pattern was changed: barley undersown with perennial grasses, treated with $\mathrm{N}_{60} \mathrm{P}_{60} \mathrm{~K}_{90}$, perennial grasses $-\mathrm{P}_{90} \mathrm{~K}_{90}$, winter triticale ${ }_{-}^{60} \mathrm{~N}_{90}^{60} \mathrm{P}_{60} \mathrm{~K}_{100}$ and spring rape $-{ }^{90} \mathrm{~N}_{120}^{90} \mathrm{P}_{90} \mathrm{~K}_{150}$. Mineral fertilisers - ammonium nitrate, granular superphosphate and potassium chloride were used in this experiment.

Soil sampling and methods of analysis. Soil samples were collected from the topsoil $(0-20 \mathrm{~cm})$ from each treatment with three replicates after harvesting in 2008 and 2011. All analyses of the soil samples were performed at the Agrochemical Research Laboratory of Lithuanian Research Centre for Agriculture and Forestry.

The following soil analyses methods were used: $\mathrm{pH}_{\mathrm{KCl}}$ - potenciometric, glass electrode; plant-available phosphorus - Egner-Riehm-Domingo (A-L); organic and mineral phosphorus amounts and different phosphate fractions were determined using the procedure of Chang and Jackson (1957), modified by Askinazi et al. (1963). Phosphorus was analysed in 7 main solutions as fraction: fraction $1-1 \mathrm{M} \mathrm{NH}_{4} \mathrm{Cl}$ solution extract all water soluble phosphates, $1^{\text {st }}$ extraction cycle (extract soluble fractions of phosphate); fraction $2-0.5 \mathrm{M} \mathrm{NH}_{4} \mathrm{~F}$ solution extract almost full aluminium phosphate, a significant amount of 
$\mathrm{CaHPO}_{4}$ and partly organic $\mathrm{P}$; fraction $3-0.1 \mathrm{M} \mathrm{NaOH}$ solution extract almost full $\mathrm{FePO}_{4}$, a significant amount of organic $\mathrm{P}$; fraction $4-0.25 \mathrm{M} \mathrm{H}_{2} \mathrm{SO}_{4}$ solution extracts the main calcium $(\mathrm{Ca})$ phosphates. Then a pretreatment was made for the extraction of hardly soluble phosphate. After this the $2^{\text {nd }}$ extraction cycle (for the extraction of less-soluble phosphates fractions) was used: fraction $5-$ $0.5 \mathrm{M} \mathrm{NH}_{4} \mathrm{~F}$ for last $\mathrm{AlPO}_{4}$; fraction $6-0.1 \mathrm{M} \mathrm{NaOH}$ extract last $\mathrm{Al}(\mathrm{Fe}) \mathrm{PO}_{4}$ and organic $\mathrm{P}$; fraction 7 - using concentrated $\mathrm{H}_{2} \mathrm{SO}_{4}+\mathrm{HClO}_{4}$ solution extracts the last insoluble phosphorus. Fractions 2, 3, 4, 5 and 6 were divided into organic, mineral and total phosphorus.

Phosphorus-related calculations: 1) amount of total organic $\mathrm{P}$ in soil was calculated by adding up the organic phosphorus amounts obtained by two extraction cycles using $0.5 \mathrm{M} \mathrm{NH}_{4} \mathrm{~F}$ and $0.1 \mathrm{M} \mathrm{NaOH}$ solutions; 2) amount of total mineral $P$ in soil was calculated by adding up the mineral phosphorus amounts obtained by two extraction cycles using $0.5 \mathrm{M} \mathrm{NH}_{4} \mathrm{~F}$ and $0.1 \mathrm{M} \mathrm{NaOH}$ solutions, and by single extraction using $1 \mathrm{M} \mathrm{NH}_{4} \mathrm{Cl}$ and $0.25 \mathrm{M} \mathrm{H}_{2} \mathrm{SO}_{4}$ solutions; 3) the obtained amounts of phosphate fractions were calculated as percentages of the soil total, organic and mineral phosphorus.

The experimental data were statistically processed by analysis of variance using the computer programANOVAfrom the package SELEKCIJA.Asterisks $*$ and $* *$ indicate the statistically significant differences between the values at $95 \%$ and $99 \%$ probability level, respectively (Tarakanovas, Raudonius, 2003).

\section{Results and discussion}

Long-term periodical liming affected the phosphorus availability in the topsoil. Sixty two years after the experiment was set up, soil analyses results revealed the changes in soil total, organic and mineral $P$ content as well as in the proportions between the different phosphorus forms.

Total phosphorus content and distribution. Our research data suggest that the accumulation of total $\mathrm{P}$ in the topsoil depends on soil acidity. Total $\mathrm{P}$ amount was slightly higher $(0.069 \%)$ in the soil with a $\mathrm{pH}_{\mathrm{KCl}}$ level of 5.6 ( 0.5 rate every 7 years $)$ compared to $\mathrm{pH}_{\mathrm{KCl}} 4.2$ (unlimed) $(0.066 \%)$, but this difference was statistically insignificant (Fig. 1).

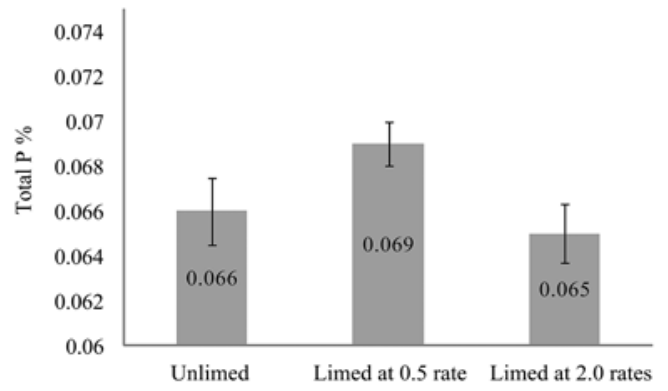

Figure 1. The amount of total phosphorus (P) in differently limed soil

Acidity of the intensively limed soil (2.0 rates every 3-4 year) was lower $\left(\mathrm{pH}_{\mathrm{KC}} 6.7\right)$ and the total amount of $\mathrm{P}$ in the topsoil $(0.065 \%)$ had a tendency to decrease. These results are consistent with the data obtained in several laboratory and field studies which suggest that liming enhances total and available $\mathrm{P}$ in soil at $\mathrm{pH}$ levels of between 5.2 and 5.5. An increasing response to applied phosphorus with increasing rates of added lime to achieve this $\mathrm{pH}$ level have been attributed to either an improved rate of supply of P by the soil or an improved ability of the plant to absorb $\mathrm{P}$ when $\mathrm{Al}$ toxicity has been eliminated (Pizzeghello et al., 2011; Sarker et al., 2014).
Organic phosphorus may represent $30 \%$ to $65 \%$ of the total soil P. In natural environments, after the mineralization, it is an essential phosphorus source for plants (Nash et al., 2014). The biggest shares of organic phosphorus were determined in the soil periodically limed using $\times 0.5$ of the liming rate $(38.9 \%$ of total $\mathrm{P})$ and in the unlimed soil (37.6\% of total P) (Fig. 2). The share of organic $\mathrm{P}$ in the more intensively limed soil was lower $-33.3 \%$ of total P. The tendency of organic P decreasing by 4.5 percentage points was observed in the soil with $\mathrm{pH}_{\mathrm{KCl}}$ 6.7. According to Shen et al. (2011), in most soils, inorganic $\mathrm{P}$ occurs at fairly low concentrations in the soil solution whilst a large proportion of it is more or less strongly held by diverse soil minerals. The poor mobility of soil inorganic $\mathrm{P}$ is due to the large reactivity of phosphate ions relative to numerous soil constituents and to the consequent strong retention of most of soil $\mathrm{P}$ onto those. Mineral $\mathrm{P}$ in an unlimed soil constituted $53.9 \%$ of the total soil P.

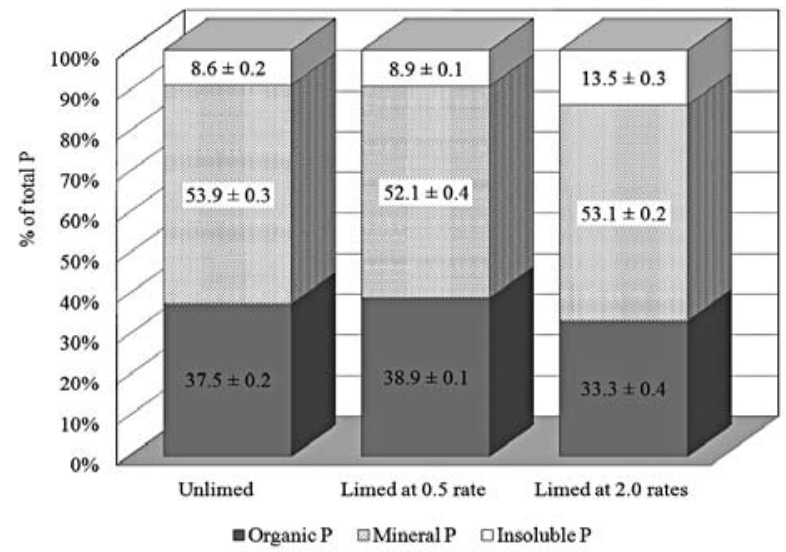

Figure 2. The distribution of phosphorus $(\mathrm{P})$ in different forms ( $\%$ of total $\mathrm{P})$ depending on liming rate

The amount of insoluble $\mathrm{P}$ in soil with nearneutral reaction (limed at 2.0 rates) was by 4.96 percentage points larger compared with unlimed soil. Our findings suggest that soil liming with higher liming rates maintains higher insoluble $\mathrm{P}$ amount in soil compared to the unlimed. These results were similar to the findings by Sarker et al. (2014) who compared phosphorus fractions across different liming rates.

Mineral phosphorus fractional composition. Liming intensity affected not only the distribution of phosphorus in soil, but also its fractional composition. Analysis of the mineral $\mathrm{P}$ fractional composition revealed that the major part of mineral P $(74.02-83.68 \%$ of total mineral $\mathrm{P}$ ) was composed of $\mathrm{Al}$ and $\mathrm{Fe}$ phosphates (extracted by the first cycles of extraction using $\mathrm{NH}_{4} \mathrm{~F}$ and $\mathrm{NaOH}$ solutions) (Table 2). These results are in accord with the recent studies indicating that in acid soil $\mathrm{P}$ is dominantly adsorbed by $\mathrm{Al} / \mathrm{Fe}$ oxides and hydroxides, because they have a large specific surface areas, which provide large number of adsorption sites and thus become unavailable to plants (Shen et al., 2011). Soil liming had a tendency to decrease solubility of $\mathrm{Al}$ and Fe phosphates with increasing soil $\mathrm{pH}$. In this way, $\mathrm{P}$ adsorbed on $\mathrm{Al} /$ Fe oxides could be released by desorption reactions and increase plant-available $\mathrm{P}$ pools in soil such as water soluble P. Water soluble P is considered available to plants in the short term or over the course of a growing season (Yang, Post, 2011). Significant increase (21.3 $\mathrm{mg} \mathrm{kg}^{-1}$ ) of water soluble phosphates was determined in the soil limed at 2.0 rates. By examining the obtained results, we observed that when soil $\mathrm{pH}$ becomes near to neutral, water soluble $\mathrm{P}$ increases compared to its value measured 
Table 2. Fractional composition of mineral phosphorus $\left(\mathrm{P}_{2} \mathrm{O}_{5}\right)$ in 0-20 cm soil layer

\begin{tabular}{|c|c|c|c|c|c|c|c|c|c|}
\hline \multirow{3}{*}{ Treatment } & \multicolumn{9}{|c|}{ Mineral $\mathrm{P}$ forms, $\mathrm{mg} \mathrm{kg}^{-1}$ of soil } \\
\hline & \multirow{2}{*}{$\begin{array}{c}\text { Water } \\
\text { soluble } \\
\text { phosphate }\end{array}$} & \multicolumn{3}{|c|}{$1^{\text {st }}$ extraction cycle } & \multicolumn{3}{|c|}{$2^{\text {nd }}$ extraction cycle } & \multirow[b]{2}{*}{$\begin{array}{c}\mathrm{Ca}^{2+} \\
\text { phosphate }\end{array}$} & \multirow[b]{2}{*}{$\begin{array}{c}\text { Mineral } \\
\mathrm{P}\end{array}$} \\
\hline & & $\begin{array}{c}\mathrm{AlPO}_{4}, \\
\mathrm{CaHPO}_{4}\end{array}$ & $\mathrm{FePO}_{4}$ & $\begin{array}{c}\% \text { of } \\
\text { mineral P }\end{array}$ & $\mathrm{AlPO}_{4}$ & $\mathrm{Al}(\mathrm{Fe}) \mathrm{PO}_{4}$ & $\begin{array}{c}\% \text { of } \\
\text { mineral P }\end{array}$ & & \\
\hline Unlimed & 8.6 & 488.3 & 260.0 & 83.7 & 9.0 & 30.3 & 4.4 & 97.9 & 894.2 \\
\hline Limed at 0.5 rate every 7 years & 4.2 & 475.0 & 251.7 & 83.0 & $12.1 *$ & 21.7 & 3.9 & 111.5 & 876.1 \\
\hline Limed at 2.0 rates every $3-4$ years & $21.3 * *$ & 354.7 & 245.8 & 74.0 & $11.3 *$ & 24.8 & 4.5 & $153.2^{*}$ & 811.2 \\
\hline $\mathrm{LSD}_{05}$ & 6.04 & 220.30 & 32.23 & & 1.90 & 6.93 & & 43.57 & 277.46 \\
\hline $\mathrm{LSD}_{01}$ & 10.02 & 365.32 & 53.44 & & 3.15 & 11.49 & & 72.25 & 460.11 \\
\hline
\end{tabular}

$*-P<0.05, * *-P<0.01$ probability level

at native $\mathrm{pH}$. Several reports have shown that over the range of soil $\mathrm{pH}$ values from 6 to 8 , the water soluble $\mathrm{P}$ was about 3-4 times higher in the intensively limed treatment than in the control soil (Devau et al., 2011).

Levels of the phosphates $\left(\mathrm{AlPO}_{4}\right.$ and $\left.\mathrm{Al}(\mathrm{Fe}) \mathrm{PO}_{4}\right)$ little-available to plants obtained by the second cycle of extraction were low $-3.9-4.5 \%$ of mineral $\mathrm{P}$ in soil. An extraction of $\mathrm{Ca}$ phosphates using $0.25 \mathrm{M} \mathrm{H}_{2} \mathrm{SO}_{4}$ solution was carried out after the first cycles of extraction using $\mathrm{NH}_{4} \mathrm{~F}$ and $\mathrm{NaOH}$ solutions. High-basicity $\mathrm{Ca}$ phosphates, obtained by this extraction, are little plant-available compared to the other group of phosphates. The size of this fraction of soil phosphates was $97.9-153.2 \mathrm{mg} \mathrm{kg}^{-1}$ $\mathrm{P}_{2} \mathrm{O}_{5}$, or $11.0-18.9 \%$ of the total mineral P. Decrease of soil acidity from $\mathrm{pH} 4.2$ to $\mathrm{pH} 6.7$ had a significant effect on the amount of phosphates belonging to this fraction. Liming at the 2.0 liming rates significantly increased the amount of $\mathrm{Ca}$ phosphates. It could be related to an increase in $\mathrm{Ca}$ adsorption by organic and mineral constituents with increasing soil $\mathrm{pH}$. Our data are consistent with those obtained in the studies conducted in acid soils, where the amount of Ca phosphates in mineral soil $\mathrm{P}$ was affected strongly by the soil $\mathrm{pH}$ and the larger amount of Ca phosphate was determined in the soil with lower soil acidity (Crews, Brookes, 2014). The results of this study are in accord with the recent studies indicating that phosphate solubility and availability to plants can be controlled with lime applications at correctly chosen rates. Liming at low rates creates optimal conditions for plant growth (Murphy, Sims, 2012, Sarker et al., 2014).

Organic phosphorus fractional composition. Soil organic P occurs in a variety of chemical forms and can be released through mineralization processes mediated by soil organisms and plant roots. These processes are highly influenced by the soil $\mathrm{pH}$. Organic $\mathrm{P}$ transformation has a great influence on the overall bioavailability of phosphorus in soil (Shen et al., 2011). Analysis of the organic P fractional composition showed that the major part (88.9-93.8\% of organic P) of organic $\mathrm{P}$ was extracted by the first cycles of extraction using $\mathrm{NH}_{4} \mathrm{~F}$ and $\mathrm{NaOH}$ solutions (Table 3 ). These phosphorus compounds are more readily mineralised because they are constituents of the newly incoming organic residues as well as of the microorganism cells. Our study showed that $\mathrm{Al}$ and $\mathrm{Fe}$ phosphates, obtained by the first extraction cycle, depended on the total amount of lime applied to the soil. The amount of $\mathrm{Al}$ and Fe phosphates (obtained by the first extraction cycle solution) had a tendency to decrease and was lower by 81.8 and $50.7 \mathrm{mg} \mathrm{kg}^{-1} \mathrm{P}_{2} \mathrm{O}_{5}$, respectively, in the soil limed at 2.0 rates compared to the unlimed soil. A possible explanation for the decrease of organic $\mathrm{P}$ at higher $\mathrm{pH}$ values might be related to the intensified microbial activity which sped up the mineralisation processes in soil. Another possible explanation for this may be the fact that liming material incorporated into the soil breaks the $\mathrm{Al}$ and $\mathrm{Fe}$ phosphates, thereby making $\mathrm{P}$ available to plant (Devau et al., 2011; Liu et al., 2013).

The amount of Al phosphates obtained by the second extraction cycle using $0.5 \mathrm{M} \mathrm{NH}_{4} \mathrm{~F}$ solution was small. The content of this fraction phosphates in the soil limed at 2.0 rates, which was near to neutral $\mathrm{pH}$, tended to decrease $\left(-1.0 \mathrm{mg} \mathrm{kg}^{-1} \mathrm{P}_{2} \mathrm{O}_{5}\right)$ compared with unlimed soil. These results are likely to be related to the soil $\mathrm{pH}$. According to the literature, soil organic $\mathrm{P}$ strongly and positively correlates with soil $\mathrm{pH}$. The correlation with $\mathrm{pH}$ contrasts markedly with most previous studies in arable soils, which have indicated that organic $\mathrm{P}$ accumulates in more acidic soils (Turner, Engelbrecht, 2011). Liming had a greater effect on the increase of little-available organic $\mathrm{P}$ fraction $\left(\mathrm{Al}(\mathrm{Fe}) \mathrm{PO}_{4}\right)$ amount in soil. An increase in little-available organic $\mathrm{P}$ content in periodically limed soils was statistically significant and varied from 18.4 to $23.5 \mathrm{mg} \mathrm{kg}^{-1} \mathrm{P}_{2} \mathrm{O}_{5}$. The observed increase in little-available organic $\mathrm{P}$ fraction could be attributed to the transformation into more stable forms, which are little available to plants at alkaline $\mathrm{pH}$.

Plant-available phosphorus. One of the main tasks of soil liming is to ensure favourable conditions for plant nutrition. Plant-available $\mathrm{P}$ is the fraction of total $\mathrm{P}$ in soil that is readily available for absorption by plant roots. The major constraint in achieving adequate phosphorus nutrition in crops arises from the fact that plant available $\mathrm{P}$ diffuses slowly through the soil solution toward roots, complicated by the fact that migrating $\mathrm{P}$ ions are susceptible to chemical fixation in most agricultural soils (Ziadi et al., 2013). Phosphorus extracted from the soil and determined using A-L method was regarded in our research as a constituent of the plant-available phosphate group. Liming enhances plant-

Table 3. Fractional composition of soil organic phosphorus $\left(\mathrm{P}_{2} \mathrm{O}_{5}\right)$ in differently limed soil

\begin{tabular}{|c|c|c|c|c|c|c|c|}
\hline \multirow{3}{*}{ Treatment } & \multicolumn{7}{|c|}{$\begin{array}{c}\text { Organic } \mathrm{P} \text { forms, } \mathrm{mg} \mathrm{kg}^{-1} \text { of soil } \\
\end{array}$} \\
\hline & \multicolumn{3}{|c|}{$1^{\text {st }}$ extraction cycle } & \multicolumn{3}{|c|}{$2^{\text {nd }}$ extraction cycle } & \multirow[b]{2}{*}{$\begin{array}{l}\text { Organic } \\
\mathrm{P}\end{array}$} \\
\hline & $\begin{array}{l}\mathrm{AlPO}_{4}, \\
\mathrm{CaHPO}_{4}\end{array}$ & $\mathrm{FePO}_{4}$ & $\begin{array}{c}\% \text { of } \\
\text { organic } \mathrm{P}\end{array}$ & $\mathrm{AlPO}_{4}$ & $\mathrm{Al}(\mathrm{Fe}) \mathrm{PO}_{4}$ & $\begin{array}{c}\% \text { of } \\
\text { organic } \mathrm{P}\end{array}$ & \\
\hline Unlimed & 285.0 & 300.0 & 93.8 & 11.1 & 27.6 & 6.2 & 623.7 \\
\hline Limed at 0.5 rate every 7 years & 273.3 & 318.3 & 90.4 & 11.6 & $51.1 * *$ & 9.6 & 654.3 \\
\hline Limed at 2.0 rates every $3-4$ years & 203.2 & 249.3 & 88.9 & 10.1 & $46.0^{* *}$ & 11.1 & 508.7 \\
\hline $\begin{array}{c}\mathrm{LSD}_{05} \\
\operatorname{LSD}_{01}\end{array}$ & $\begin{array}{l}136.86 \\
227.00\end{array}$ & $\begin{array}{l}43.31 \\
71.83\end{array}$ & & $\begin{array}{l}2.80 \\
4.57\end{array}$ & $\begin{array}{c}8.32 \\
13.80\end{array}$ & & $\begin{array}{l}183.30 \\
304.00\end{array}$ \\
\hline
\end{tabular}

$* *-P<0.01$ probability level 
available $\mathrm{P}$ in soil. An increasing rate of added lime improves rate of phosphorus supply in soil and improves ability of the plant to absorb phosphorus. Plant-available P status increase may be due to increase in mineralization of organic $\mathrm{P}$ as affected by lime. This was because $\mathrm{Ca}^{2+}$ ions contained in lime displaced the $\mathrm{H}^{+}, \mathrm{Mn}^{4+}, \mathrm{Fe}^{3+}$ and $\mathrm{Al}^{3+}$ ions from the soil adsorption sites resulting in increase in soil $\mathrm{pH}$. Therefore, the increase in soil available $\mathrm{P}$ could be due to the reduction in phosphorus fixation by $\mathrm{Al}$ and $\mathrm{Fe}$ oxides effected of lime (Kisinyo et al., 2012; Ziadi et al., 2013). Data presented in Table 4 indicate that the amounts of plant-available $\mathrm{P}$ taken up by the plants in acid soil were quite small $-186 \mathrm{mg} \mathrm{kg}^{-1}$ $\mathrm{P}_{2} \mathrm{O}_{5}$, or $20.8 \%$ of total $\mathrm{P}$ (Table 4 ).

Table 4. The content of plant-available phosphorus $\left(\mathrm{P}_{2} \mathrm{O}_{5}\right)$ in soil

\begin{tabular}{lcc}
\hline \multicolumn{1}{c}{ Treatment } & $\begin{array}{c}\mathrm{P}_{2} \mathrm{O}_{5} \\
\mathrm{mg} \mathrm{kg}^{-1}\end{array}$ & $\begin{array}{c}\text { \% of total } \\
\mathrm{P}\end{array}$ \\
\hline Unlimed & 186 & 20.80 \\
Limed at 0.5 rate every 7 years & 192 & 21.91 \\
Limed at 2.0 rates every 3-4 years & $222^{*}$ & 27.37 \\
\hline $\mathrm{LSD}_{05}$ & 28.27 & \\
$\mathrm{LSD}_{01}$ & 39.64 & \\
\hline
\end{tabular}

\section{* $-P<0.05$ probability level}

Significantly larger plant-available phosphorus amount was determined in the soil limed at 2.0 rates. It was higher by $36 \mathrm{mg} \mathrm{kg}^{-1} \mathrm{P}_{2} \mathrm{O}_{\text {r }}$, or $6.57 \%$ of the total $\mathrm{P}$ compared to the unlimed soil. These results are consistent with those of Sarker et al. (2014) who determined that an increase of plant-available $\mathrm{P}$ status may be related to increase in mineralization of organic $P$ as affected by lime. Also, the obtained results could be explained by the relatively good correlation between organic matter and phosphorus by the interaction of oxides with organic matter that considerably reduces phosphorus binding sites in the former and increases the amount of plant-available P (Heredia, Cirelli, 2007; Cui et al., 2011).

With increasing demand for agricultural production, significant progress has been made in understanding soil and plant processes associated with soil $\mathrm{P}$ transformation, phosphorus mobilization and P-deficiency responses. However, many aspects of overall phosphorus dynamics in the soil are not thoroughly understood, including regulation of $\mathrm{P}$ availability and supply in soil, especially in acid soil. According to our study, the relatively optimal amounts of phosphorus forms and fractions, that are in soluble forms and available for plants, were determined in soil with $\mathrm{pH}_{\mathrm{KCl}} 5.6$ achieved by liming with 0.5 rate every 7 years. In this way, soil liming can ensure phosphorus supply in soil and improve ability of the plant to absorb phosphorus. Soil liming at 2.0 rates every 3-4 years increased the amount of $\mathrm{Ca}$ phosphates. Thus, there is a risk to increase the amount of little available to plants phosphate fractions in soil. Our findings have significant implications for the better understanding of phosphorus dynamics in the soil and establishment of integrated P-management strategies for better decision making about agro-environmental management in sustainable cropping systems in the future.

\section{Conclusions}

1. The long-term liming affected the changes of phosphorus (P) compounds in a moraine loam Bathypogleyic Dystric Glossic Retisol. Accumulation of the total $\mathrm{P}$ in the arable layer of soil had a tendency to decrease with increasing soil $\mathrm{pH}$. The lowest amount of the total $\mathrm{P}$ was determined in soil with $\mathrm{pH}_{\mathrm{KCl}}$ 6.7.

2. Soil liming had no significant effect on the distribution of phosphorus, but the tendency of organic $\mathrm{P}$ decreasing by 4.6 percentage points and insoluble $\mathrm{P}$ increasing by 4.9 percentage points in the soil with $\mathrm{pH}_{\mathrm{KCl}}$ 6.7 compared with unlimed soil was observed.
3. Major part of mineral P (74.02-83.68\% of total mineral P) was composed of Al and Fe phosphates. Soil liming had a tendency to increase solubility of $\mathrm{Al}$ and $\mathrm{Fe}$ phosphates with increasing soil $\mathrm{pH}$ and increase plant-available P pools such as water soluble P in soil. Decrease of soil acidity from $\mathrm{pH} 4.2$ to $\mathrm{pH} 6.7$ had a significant effect on the amount of little plant-available Ca phosphates.

4. The largest share $(88.9-93.8 \%$ of organic $\mathrm{P})$ of organic $\mathrm{P}$ was composed of readily mineralised $\mathrm{Al}$ and Fe phosphates. Soil liming at the higher liming rates had a tendency to decrease the amount of Al and Fe phosphates and increase of little available organic $P$ fraction amount in soil.

5. Liming enhances plant-available $P$ amount in soil. A reduction of soil acidity to close to neutral soil $\mathrm{pH}$ values $\left(\mathrm{pH}_{\mathrm{KCl}} 6.7\right)$ improved the rate of phosphorus supply in the soil and enhanced the ability of plants to absorb phosphorus. The relatively optimal amounts of phosphorus forms and fractions available for plants were determined in soil with a $\mathrm{pH}_{\mathrm{KCl}}$ of 5.6, achieved by liming with 0.5 rate every 7 years.

\section{Acknowledgments}

The research was part of the long-term LRCAF programme "Productivity and Sustainability of Agricultural and Forest Soil". Part of this research was provided by the project No. VP1-3.1-ŠMM-01-V-03-002 BIOMEDOKT.

Received 09062014 Accepted 27072015

\section{References}

Askinazi D. L., Ginzburg K. E., Lebedeva L. S. 1963. Mineral phosphorus compounds in soil and methods of its determination. Soil Science, 5: 27 (in Russian)

Bünemann E. K., Smernik R. J., Marschner P., McNeill A. M. 2008. Microbial synthesis of organic and condensed forms of phosphorus in acid and calcareous soils. Soil Biology and Biochemistry, 40 (4): 932-946 http://dx.doi.org/10.1016/j.soilbio.2007.11.012

Chang S. C., Jackson M. L. 1957. Fractionation of soil phosnhorus. Soil Science, 84: 133-144 http://dx.doi.org/10.1097/00010694-195708000-00005

Condron L. M., 'Iurner B. L., Cade-Menun B. J. 2005. Chemistry and dynamics of soil organic phosphorus. Sims J. T., Sharpley A. N. (eds.). Phosphorus: agriculture and the environment. American Society of Agronomy. Madison, USA, p. 87-121

Cordell D., Drangert J. O., White S. 2009. The story of phosphorus: global food security and food for thought. Glohal Fnvironmental Change, 19: 292-305 http://dx.doi.org/10.1016/j.gloenvcha.2008.10.009

Crews 'I.E., Brookes P.C.2014. Changes in soll phosphorus forms through time in perennial versus annual agroecosystems. Agriculture. Fcosvstems and Fnvironment. 184: 168-181 http://dx.doi.org/10.1016/j.agee.2013.11.022

Cui H. J., Wang M. K., Fu M. L., Ci E. 2011. Enhancing phosphorus availability in phosphorus-fertilized zones by reducing phosphate adsorbed on ferrihydrite using rice straw-derived biochar. Journal of Soils and Sediments. 11: 1135-1141 http://dx.doi.org/10.1007/s11368-011-0405-9

Devau N., Hinsinger P., Le Cadre E., Colomb B., Gerard F. 2011. Fertilization and $\mathrm{pH}$ effects on processes and mechanisms controlling dissolved inorganic phosphorus in soils. Geochimica et Cosmochimica Acta, 75: 2980-2996 http://dx.doi.org/10.1016/j.gca.2011.02.034

Elser J., Bennett E. 2011. Phosphorus cycle: a broken biogeochemical cycle. Nature, 478: 29-31 http://dx.doi.org/10.1038/478029a

Heredia O. S., Cirelli A. F. 2007. Environmental risks of increasing phosphorus addition in relation to soil sorption canacity. Geoderma, 137: 426-431 http://dx.doi.org/10.1016/j.geoderma.2006.09.005

Kisinyo P. O., Gudu S. O., Othieno C. O., Okalebo J. R., Opala P. A., Maghanga J. K., Agalo J. J., Ng'etich W. K., Kisinyo J. A., Osiyo R. J., Nekesa A. O., Makatiani E. T., Odee D. W., Ogola B. O. 2012. Effects of lime, phosphorus and rhizobia 
on Sesbania sesban performance in a Western Kenyan acid soil. African Inurnal of A gricultural Research. 7 (18): 2800-2809 http://dx.doi.org/10.5897/AJAR11.1450

Liu Z. P., Shao M. A., Wong Y. Q. 2013. Spatial patterns of soil total nitrogen and soil total phosphorus across the entire I ness Plateau region of China. Genderma, 197-198: 67-78 http://dx.doi.org/10.1016/j.geoderma.2012.12.011

Makarov M. I., Haumaier L., Zech W., Marfenina O. E., Lysak L. V. 2005. Can 31PNMR spectroscopy be used to indicate the origins of soil organic nhosnhates? Soil Biology and Biochemistry. 37 (1): 15-25 http://dx.doi.org/10.1016/j.soilbio.2004.07.022

McLaughlin M. J., McBeath I. M., Smernik R., Stacey S. P., Ajiboye B., Guppy C. 2011. The chemical nature of P accumulation in agricultural soils - implications for fertiliser management and design: an Australian perspective. Plant and Soil. 349 (1-2): 69-87 http://dx.doi.org/10.1007/s11104-011-0907-7

Moazed H., Hoseini Y., Naser1 A. A., Abbasi F. 2010. Determining phosphorus adsorption isotherm in soil and its relation to soil characteristics. International Journal of Soil Science, 5: 131-139 http://dx.doi.org/10.3923/ijss.2010.131.139

Murphy P. N. C., Stevens R. J. 2010. Lime and gypsum as source measures to decrease phosphorus loss from soils to water. Water Air and Soil Pollution. 2012 (1-4): 101-111 http://dx.doi.org/10.1007/s11270-010-0325-0

Murphy P. N. C., Sims J. I. 2012. Etfects of lime and phosphorus application on phosphorus runoff risk. Water, Air and Soil Pollution. 223 (8): 5459-5471 http://dx.doi.org/10.1007/s11270-012-1293-3

Nash D. M., Haygarth P. M., Turner B. L., Condron L. M., McDowell R. W., Richardson A. E. Watkins M., Heaven M. W. 2014. Using organic phosphorus to sustain pasture nroductivity: a nersnective. Geoderma. 221-222: 11-19 http://dx.doi.org/10.1016/j.geoderma.2013.12.004

Noack S. R., McLaughlin M. J., Smernik R. J., McBeath I. M., Armstrong R. D. 2012. Crop residue phosphorus: speciation and potential hio-availahility. Plant and Soil, $359(1-2)$ : 375-385 http://dx.doi.org/10.1007/s11104-012-1216-5

Pizzeghello D., Berti A., Nardi S. Morari F. 2011. Phosphorus forms and P-sorption properties in three alkaline soils after long-term mineral and manure applications in north-eastern Italy. Agriculture. Fcosvstems and Fnvironment, 141: 58-66 http://dx.doi.org/10.1016/j.agee.2011.02.011

Sarker A., Kashem M. A., Usman K. I. 2014. Phosphorus availability, uptake and dry matter yield of Indian spinach (Basella alba L.) to lime and phosphorus fertilization in an acidic soil. Onen Iournal of Soil Science 4 (1): 42-46 http://dx.doi.org/10.4236/ojss.2014.41006

Shen J., Yuan L., Zhang J., Li H., Bai Z., Chen X., Zhang W., Zhang F. 2011. Phosphorus dynamics: from soil to plant. Plant Physiology, 156: 997-1005 http://dx.doi.org/10.1104/pp.111.175232

Tarakanovas P., Raudonius S. 2003. Agronominiu tyrimu duomenu statistine analizè taikant kompiuterines programas $A N O V A$, STAT, SPLIT-PLOT iš paketo SELEKCIJA ir IRRISTAT. Lithuanian University of Agriculture, 58 p. (in Lithuanian)

Tripolskaja L. 2003. The changes in phosphoric forms and fractions of mineral phosphorus on Haplic Luvisol in response to the application of organic fertilizers and liming. Zemdirbyste-Agriculture, 81 (1): 44-63 (in Lithuanian)

Turner B. L., Engelbrecht B. M. J. 2011. Soil organic phosphorus in lowland tronical rain forests. Ringenchemistry 103: 297-315 http://dx.doi.org/10.1007/s10533-010-9466-x

Wang T., Arbestain M. C., Hedley M., Bishop P. 2012. Predicting phosphorus bioavailability from high-ash biochars. Plant and Soil, 357: 173-187 http://dx.doi.org/10.1007/s11104-012-1131-9

World reference base for soil resources. 2014. International soil classification system for naming soils and creating legends for soil maps. World Soil Resources Reports No. 106. FAO, Rome, $181 \mathrm{p}$

Yang X., Post W. M. 2011. Phosphorus transformations as a function of pedogenesis: a synthesis of soil phosphorus data using Hedley fractionation method. Bingensciences, 8: 2907-2916 http://dx.doi.org/10.5194/bg-8-2907-2011

Ziadi N., Whalen J. K., Messiga A. J., Morel C. 2013. Assessment and modelling of soil available phosphorus in sustainable cropping systems. Sparks D. L. (ed.). Advances in Agronomy, vol. 122, n. 85-126

http://dx.doi.org/10.1016/B978-0-12-417187-9.00002-4

ISSN 1392-3196 / e-ISSN 2335-8947

Zemdirbyste-Agriculture, vol. 102, No. 3 (2015), p. 251-256

DOI $10.13080 /$ z-a.2015.102.032

\title{
Fosforo formų ir frakcijų pasiskirstymas nepasotintame balkšvažemyje kalkinant skirtingu intensyvumu
}

\author{
I. Jokubauskaitè ${ }^{1}$, D. Karčauskienè ${ }^{1}, \check{S}_{\text {. Antanaitis }}^{2}$, J. Mažvila² , A. Šlepetiené3 \\ D. Končius ${ }^{1}$, L. Piaulokaitè-Motuziené ${ }^{1}$ \\ ${ }^{1}$ Lietuvos agrarinių ir miškų mokslų centro Vėžaičių filialas \\ ${ }^{2}$ Lietuvos agrarinių ir miškų mokslų centro Agrocheminių tyrimų laboratorija \\ ${ }^{3}$ Lietuvos agrarinių ir miškų mokslų centro Žemdirbystės institutas
}

\section{Santrauka}

Lietuvos agrarinių ir miškų mokslų centro Vèžaičiu filiale 2008 ir $2011 \mathrm{~m}$. stacionariame bandyme natūraliai rūgščiame ir pakalkintame moreninio priemolyje (Bathypogleyic Dystric Glossic Retisol) buvo atlikti fosforo frakcijų pasiskirstymo tyrimai. Tyrimų tikslas - nustatyti ịvairiu fosforo formų ir frakcijų pasiskirstymą natūraliai rūgščiame ir ilgą laiką (62 metus) kalkintame dirvožemyje. Tyrimu laikotarpiu i dirvožemi iterptas nevienodas kalkinių medžiagų kiekis $\left(18,4\right.$ ir 104,9 $\left.\mathrm{tha}^{-1}\right)$ lèmé skirtingų $\mathrm{pH}_{\mathrm{KCl}}$ lygių - rūgštoko $\left(\mathrm{pH}_{\mathrm{KCl}} 5,6\right)$ ir artimo neutraliam $\left(\mathrm{pH}_{\mathrm{KCl}} 6,7\right)$ - susiformavimą. Dirvožemyje nustatytos 7 mineralinio bei organinio fosforo frakcijos ir augalams pasiekiamo fosforo $\left(\mathrm{P}_{2} \mathrm{O}_{5}\right)$ kiekis.

Nustatyta, kad dirvožemio ilgalaikis kalkinimas neturèjo esminès ịtakos suminio fosforo kiekiui ir jo pasiskirstymui, tačiau lèmè nevienodą fosforo frakcijų pasiskirstymą. Vertinant fosforo frakcinę sudètị nustatyta, kad didžiają dalị organinio $(88,9-93,8 \%)$ ir mineralinio $(74,02-83,68 \%)$ fosforo sudare aliuminio bei geležies fosfatai. Dirvožemio kalkinimas 2,0 normomis kas 3-4 metus esmingai padidino mažai tirpių aliuminio ir geležies fosfatu kieki, išekstrahuotu antrojo ekstrakcijos ciklo metu. Kai dirvožemio $\mathrm{pH}$ tampa artimas neutraliam, vandenyje tirpių ir augalams pasiekiamu fosforo frakcijų kiekis esmingai padidejja, palyginus su natūraliu dirvožemio $\mathrm{pH}$. Dirvožemio rūgštumo sumažéjimas $\left(\mathrm{pH}_{\mathrm{KCI}} 6,7\right)$ turèjo reikšmingos ịtakos mažai tirpių kalcio fosfatu ir organinio fosforo frakcijų kiekiams. Santykinai optimalūs tirpiu fosforo frakcijų, kurios yra augalų pasisavinamos, kiekiai nustatyti dirvožemyje, kurio $\mathrm{pH}_{\mathrm{KCl}} 5,6$ (kalkintame 0,5 normos kas 7 metus).

Reikšminiai žodžiai: fosforo frakcijos, kalkinimas, organinis ir mineralinis fosforas, rūgštus dirvožemis. 